\title{
BOSNIAN-HERZEGOVINIAN AND MONTENEGRIN LITERATURE AMONG IVAN FRANKO'S CREATIVE INTERESTS
}

\author{
IVan TEPLYY \\ The Ivan Franko National University of Lviv, \\ 1 Universytets'ka Str., 79000, Lviv \\ The Department of Foreign Languages for Humanities \\ e-mail: i_teplyy@yahoo.co.uk
}

The paper deals with scholarly-critical works, literary-artistic translations, touching upon the issue raised, literary studies and translation studies research based on the declared and related issues (translations, figurative analogies, other forms of implementing the foreign-language discourse, actively developed and implemented by I. Franko himself). The focus of the study is Luca Jovović, whose first publication the storiette Hayduky (orig.: "Hajduci”, „Luča” magazine, 1895) - I. Franko translated and and included a literary theoretical reference information about the author.

Ivan Franko's creative translation work in this area is not so quantitatively large, but it gives an opportunity to illustrate a number of important theoretical issues, has a significant heuristic potential, and is of a great theoretical value, which, by the way, has provided the basis for a number of researchers to make important theoretical conclusions.

In his well-known article, "Internationalism and Nationalism in Modern Literatures", I. Franko, exemplifying, in particular, on the Montenegrin Luka Jovović, substantiated the idea of proximity of the national in form creativity of writers to universal human feelings, viz. such a writer will be simultaneously understandable and interesting not only for his countrymen, but also for the whole civilized world, for everyone will find in his writings, despite the unusual nature and national originality of their form, the same feelings, doubts, suffering, sympathy and antipathies constituting the essence of the educated personality of his/her time.

The issues of intertextuality, literary and academic ties, contacts occupy a place of importance in the research.

In view of this, the next step, i.e. study of the issue in question, could well be an analysis of I. Franko's translation of Luka Jovović's storiette Hajduci, based on verifying the original and its Ukrainian version.

Key words: discourse, translation, literature, storiette, essence, form, national, universal.

The stated problem presupposes a number of dimensions to be examined, viz.: scholarly and critical papers touching upon the issues in question, translation and translation studies works based on this set of problems, figurative analogies and other forms of assimilating a foreign language text elaborated and actively implemented by I. Franko himself. Intertextuality counts here as well.

The following works by I. Franko put under respective headings are to be taken into account here: From Montenegrin literature. Luka Jovović. The Hajduks. A Storiette from

(C) Teplyy, I., 2018 
the Montenegrins' Life, i.e. Hayduky. Obrazok z zhyttia chornohortsiv (Франко, 2008, 51, c.803-812) + Commentaries (Франко, 2008, 51, с.947-948). From Serbian Folk Poetry. How Christ Was Baptized, i.e. Yak Khrystos Khrestyvsia + Commentaries (Франко, 2008, 52, с.727-728; 988-989). From Bosnian-Herzegovinian Folk Poetry (Франко, 2008, 52, c.729-736). Here belong: a) Serpent the Prince, i.e. Zmyi-Korolevych (Франко, 2008, 52, c.729-732) + How Jug Bogdan Sold His Wife, i.e. Yak Yuh Bohdan svoyu zhinku prodav (Франко, 2008, 52, c.733-736) + Commentaries (Франко, 2008, 52, с.989-990) + Vol. 10 of I. Franko's Completed Works etc. (Франко, 1977, 10, c.73-108).

For the first time, Hayduky (original: "Hajduci" u "Luči" 1895) was published in the Literary-Scientific Herald [Literaturno-Naukovyi Vistnyk, LNV] for the year 1898, Vol.1, Book 1, pp.103-113 (Франко, 2008, 51, с.947; Йовович, 1898), the source language being Croatian (Йовович..., 1898 (online). The source of the translation is the original's first print of the Hayduky in the Montenegrin literary magazine Luča [The Ray] $^{1}$ (Франко, 2008, 51, c.948), 1895, authored by Luka Jovović (1865-1944) (Lekić, 2018, c.349), whereas Vol.51 cites the following data: “Йовович (Јововић) Лука (1865-1916) - Montenegrin writer, rural teacher living in Montenegro and writing in the local patois of the Serbian, as then treated, language. Prior to the collapse of Yugoslavia, it had been officially believed that the Montenegrins speak the Shtokavian dialect of the Serbo-Croatian language" (Франко, 2008, 51, c.947).

The most reliable, so it appears, data stem from in the following source: Luka Jovović (Gluhi Do kod Virpazara, 1865. - Bar, 1944.) crnogorski je književnik i prosvjetni radnik. [Montenegrin writer and educator]. Biografija. Završio je Nižu gimnaziju na Cetinju, nakon čega se posvetio pedagoškome radu kao učitelj u nekoliko mjesta u Crnoj Gori [Biography. He graduated from the Lower Grammar School in Cetinje, following which he devoted himself to pedagogical work as a teacher in several places in Montenegro]. Bio je učesnik balkanskih i Prvoga svjetskog rata [Participated in the Balkan wars and the First World War]. Pisao je pripovijetke, a bavio se i skupljanjem folklorne građe [Wrote narratives, also collected folklore material]. Objavio je dvije zbirke pripovjedaka pod zajedničkim nazivom Pripovijetke iz crnogorskog života. [He has published two collections of narratives under the common title Stories from Montenegrin life]. U prvu knjigu autor je uvrstio devet priča (Ko neće čepom, on će vranom, Kopanje blaga, Hajduci, Nametnut prsten, Do podne vezir, od podne rezil, Blago njegovoj duši, Jetrve I Prije i sad ili Sedam noći kod đeda Jova). [The author included nine stories in the first book (He Who Doesn't Get Involved, Is Thrown Away, The Digging Up of Treasures, The Haiduks / Brigands, A Ring Put On; By Midday a Vizier, In the Afternoon a Cut-Throat; Blessed Be His Soul; ? Sister-in-Law before and Now, or Seven Nights at Grandfather Jove's)]. U drugoj knjizi Pripovijedaka nalazi se osam priča [There are eight stories in the second book of the Short Stories] (Vjeridba na Veliki petak na Viru [Verification on Good Friday at Vir], Preudala se [She was Scared], Crnogorski ranjenici [Montenegrin Wounded], Sud dobrih ljudi [The Court of Good People], Stijepo [Stijepo], Svekrva [Mother-in-Law], Kum Stijepo[Godfather Stijepo] i Popravio se [He Corrected Himself]). Works: Pripovijetke iz crnogorskog života, knj. I (Cetinje, 1895) [Stories from Montenegrin Life, Book I]. Pripovijetke iz crnogorskog života, knj. II (Dubrovnik, 1896) [Stories from Montenegrin Life, Book II]. Source: Nikola Racković, Leksikon crnogorske kulture, DOB, Podgorica, 2009. Milorad Nikčević, Istorija crnogorske književnosti, knj. III, ICJK, Podgorica, 2012 [LUKA JOVOVIC...].

\footnotetext{
${ }^{1}$ Literary gazette, printed organ of the Hirs'kyi vinets' (Mountain Crown) society; came out in 1895-1900, city of Cetinje, (Montenegro).
} 
A number of other authors on the subject do not give the years of L.Jovović's life (Sabljic, 2017). The reference is normally made to Savo Lekić [LUKA JOVOVIĆ ...].

Ivan Franko owes the translation of the work to Friedrich Salomo Krauss (1859-1936) [Friedrich Salomon (online)], an Austrian folklorist and ethnographer, translator from Slavonic languages, publisher and editor of folklore materials of various peoples, in particular "Sagen und Märchen der Südslaven in ihrem Verhältnis zu den Sagen und Märchen der übrigen indogermanischen Völkergruppen" [Legends and Tales of the Southern Slavs in Their Relation to the Legends and Tales of the Other Indo-Germanic Groups of Peoples] in a German translation whose first volume (I Band. Sagen und Märchen der Südslaven. Zum grossen Teil aus ungedruckten Quellen. Leipzig. Verlag von Wilhelm Friedrich, 1883) I. Franko reviewed in writing (Франко, 26, c.285-288). First published in the Zoria [The Star] journal, 1883, No.12, p.201-202. Krauss F.S. (1858-1936) - German ethnographer, publisher and editor of folklore material of various peoples (Франко, 26, c.435).

The years of F.S.Krauss's birth are in conflict, as one can see, too. The folklore material of F.S.Krauss was first published in the the Zhyttie i slovo [Life and Word] journal, 1894, Vol.1, Book 2, pp.312-313 (Франко, 53, с.751).

I.Franko visited F.S. Krauss in Vienna, was in correspondence with him [Франко, 51, c.948]. In a review article, Ukrayins'ka literatura za 1898 rik [Ukrainian Literature for the Year 1898", he noted that the $L N V$ [Literary and Scientific Herald, Ukrainian acronym] in its issue of the year 1898 had also placed the work by L.Jovović: "In the newly founded (late 1897) Literary and Scientific Herald... Slavonic literatures were not neglected either..., the journal published translations from Russian writers - Chekhov, Mamin-Sibiriak, Nadson; Polish - Orzheszkowa and Dombrowski; Czech ones - Machar, Serbian - Jovović (Франко, 32 , c.11). Montenegro gained independence from the Ottoman yoke back in 1796, and the events take place in the 1830s on the borders of the Turkish and Montenegrin dominations (Франко, 51, с.947). In the note (foot-note) to the story - hallmark of the translation method I. Franko writes: "This splendid short novella of the Montenegrins' life in not too age-old, as it is of the 30s of our century [the 1830s - I. T.], written by Luka Jovović, a teacher in the village Mrkojević in Montenegro, was published together with the second short novella in the first yearbook of the literary magazine Lис̆a [Луча], published by the society Gorski vijenac [The Mountain Wreath] in Cetinje, beginning with 1895. One of those stories was translated by the well-known folklorist F.S. Krauss into German and published in issue 37 of the Vienna-based weekly Die Zeit, the translator adding from himself words of recognition for the talented author. "But in Cetinje - Mr. Krauss writes, lending me the first issue of the $L u \check{c} a$ for my translation "someone" looked awry at the fact of so much honour having been done to the rural teacher, poor thing - and they stopped sending Luča to me" (Франко, 51, c.803). This page carries two more foot-notes, among which hajduci, and, on the page to follow - cami [Turkish temple, i.e. mosque].

In the article Internatsionalizm $i$ natsionalizm u suchasnykh literaturakh [Internationalism and Nationalism in Modern Literatures], I. Franko substantiated, in particular by exemplifying the Montenegrin Luka Jovović, the idea of proximity of the - national by form - writers' creativity to the common sentiments of the people: "And only such a writer will be simultaneously understandable and interesting not only to his closest fellowcountrymen, but also to the whole civilized world, for everyone will find in his works, no matter how much unusual and uniquely national their form might be (let us take, for example, the works of our Shevchenko, the Englishman Dickens, American Mark Twain, Magyar Mikszáth 
or the Montenegrin Jovović), the same sentiments, doubts, sufferings, likes and dislikes, making up the essence of the present-day educated man's soul" (Франко, 31).

Question is posited about I. Franko's lessons in the field of Translation Studies. The first lesson is: "Translation studies should become the branch that does not disunite Humanities, but unites them, for translation is neither purely linguistic, nor purely literary phenomenon. Translation is a cultural phenomenon [italics ours - I. T.], because I. Franko translated not only from one language into another, but from an epoch to another, from one system of thinking to another. All is subordinated to this. And this is a very important lesson by I. Franko. [...]. Every time, we must talk about the aim of translation. "Why did I. Franko translate Yolović [Jovović - I. T.], a Montenegrin writer, beginner, his first work, he himself almost unknown among the Serbs and Montenegrins alone?" For in the work of Yolović [Jovović], he found the unity of international and national, which is an important moment in the history of culture. And generally, when talking about translation, we must talk of the important cultural-forming mission by I. Franko [italics ours - I. T.] which considers culture as a complex, dynamic, contradictory, yet, simultaneously, integral system. When talking about I. Franko, we should not talk about whether he has achieved or not achieved, whether he has reached, or he has not reached, we must speak about a great cultural phenomenon [italics ours. - I. T.], and from this follows what touches upon translation" (Гольберг, 1989, с.298-299).

I. Franko's second lesson teaches us that "both the original and the translation constitute an integrity. And if render it into the language of our century which I. Franko, understandably, did not know, everything is, according to him, intersubordinated. And it is a little strange, in this respect, that there have been few reports of brilliant analyses by Ivan Franko of translations from oral folklore, or, say, we have not spoken here about his own translations of the Balkan Slavs' folklore, which is very characteristic, as I. Franko himself comments on them in terms of the integrity of translation, when each component is subordinated to some major thematic task. The third issue is the issues of the translator's repertoire. According to Ivan Franko and our concepts, translation is a form of interaction between literatures. Once it is so, then the law of selectivity, substantiated by I. Franko, operates here. One more lesson by I. Franko. We all keep repeating "reproduced". Translation cannot be reproduction only. The practice of I. Franko himself shows that $[\ldots]$ translation is a dialectic phenomenon. It is a unity of reproduction and creativity. If it were just a reproduction, then there would be no creative individuality pulsating in it, the translator's interest would not be felt, it would not be a living phenomenon of artistic culture. Translation is as much reproduction, as it is creativity, and vice versa. But when we talk about this creativity, it is clear that it is subject to the task of rendering certain aspects of the original" (Гольберг, 1989, с.298-299).

The translation legacy of I. Franko in the field indicated above includes: Zmyi Korolevych [The Prince of a Serpent]. Work from I. Franko's manuscript legacy. Original of the translation: "Narodne pijesme bosanske i hercegovačke" [Folk Songs Bosnian and Herzegovinian]. Compiled by Jovan Jukić and Grga Martić (Osijek: Lehmann, 1858). Chapter I - Pijesme junačke [Heroic Songs]. Number of the work -5 , p.76-80. The translation's dating is not specified (Франко, 52, c.989; See also: Hajdarpasic, 2015, c.220).

Volume 52 (Франко, 52, с.990) includes the following material: Yak Yug Bogdan svoyu zhinku prodav [How Jug Bogdan Sold His Wife] (Manuscript Institute. The V. Vernadskyi National Library of Ukraine I, 4931-б, sheet 10-12). Work at these translations is not complete. Second translation dated: 22.VI [18]93. There is a plot parallel to this work (see Вук Караџић, “Народне српски пјесме”, кн. I, №725) [Vuk Karadžić. Serbian Folk Songs]. These works are published for the first time, by the autographs indicated. 
The very translation of the Hajduci into Ukrainian needs a special research, although researchers differ in their estimation of I. Franko's prose translations from the SouthSlavonic languages (Гольберг, 1965, 2006; Гуць, 1966; Хајдуковић, 2006).

Jakov Sabljić in his paper "Pregled Crnogorske književnosti od 1852 do 1918 Milorada Nikčevića" [Review of Montenegrin Literature from 1852 to 1918 by Milorad Nikčević] indicates, in particular, that the most significant representatives of the short story on folk life, symbolizing the transition from Romanticism to Realism (particularly in the late 1870s 1890 s, to a lesser extent in the early $20^{\text {th }}$ c.), were Luka P. Jovović, Savo P. Vuletić, Andrija Jovićević and Novica Kovačević Grahovski (Sabljić , 2017, c.330-331), Luka P. Jovović occupying the place of paramount importance, leading the honorary line of the illustrious authors. The progenitor of the genre, as it were, was M. Nikčević who, from Njegoš's death (1852) till the end of WWI (1918), writes his most significant folklore and didactic stories, thematically spearheading the problems of an ordinary, everyday life, in particular that of villagers, and are largely based on the oral tradition (Sabljić, 2017, c.330). Some other major present-day works on the subject do not, regrettably, mention the name of Luka P. Jovović (Leksikon hrvatskog jezika..., 2001, Recepcija i novocitanje..., 2013).

Statistics of I. Franko's Translation Work in the Field of the Literatures in Question

\begin{tabular}{|c|c|c|c|c|}
\hline Literature & Authors & Works & $\begin{array}{c}\text { Amount } \\
\text { of pages }\end{array}$ & $\begin{array}{c}\text { Language } \\
\text { source, } \\
\text { intermediary) }\end{array}$ \\
\hline $\begin{array}{c}\text { Bosnian- } \\
\text { Herzegovinian }\end{array}$ & 2 & 2 & 8 & $\begin{array}{c}\text { Croatian - } \\
\text { source language }\end{array}$ \\
\hline Serbian & 2 & 12 & 39 & $\begin{array}{c}\text { Serbian } \\
\text { source language }\end{array}$ \\
\hline Montenegrin & 1 & 1 & 10 & $\begin{array}{c}\text { Montenegrin - } \\
\text { source language }\end{array}$ \\
\hline
\end{tabular}

Conclusions. One should differentiate between I. Franko's creative style as translator of poetry and that of prose. There seems to be an antinomy between them on the material of Serbian literature (successful in terms of poetry, yet not so felicitous in the rendering of prose), but much less so on that of the literatures indicated here, judging by even a cursory glance at the issue.

Therefore, the next step, i.e. paper on the problem, should well be an analysis of I. Franko's translation of Hajduci as based on Luka Jovović's original.

The creative translation output is not too numerous in the domain under consideration, being, simultaneously, illustrative and instructive, showing great theoretical value, giving grounds for profound conclusions on the part of other researchers.

\section{Список посилань}

Гольберг, М. Я., 1965. Франкові переклади з сербської прози. Слов'янське літературознавство і фольклористика, 1, с.160-172.

Гольберг, М. Я., 1990. [Обговорення]. Іван Франко і світова культура: Матеріали міжнародного симпозіуму ЮНЕСКО (Львів, 11-15 вересня 1986). У 3-х кн. Кн. 2. Київ: Наукова думка, с.298-300.

Гольберг, М. Я., 2006. Виявлення українсько-сербських літературних взаємин: підсумки та перспективи. В: Б. Косановић, уред. Иван Франко и срби: Зборник радова 
са међународног симпозијума одржаног у Новом Саду 25-27. новембра 1996. Нови сад: Српско-украјинско друштво: Архив Војводине.

Гуць, М. В., 1966. Південнослов'янський гайдуцький епос та сербохорватська народна лірика в перекладах I. Я. Франка. В: М. В., Гуць. Сербохорватська народна пісня на Україні. [online] Доступно: http//rastko.rs> rastko-ukr/au/guc_pisnja_kn.html [Дата звернення 16 лютого 2017]

Йовович, Л., 1898. Гайдуки: образок з життя Чорногорців. 3 хорв. пер. Ів[ан] Фр[анко]. Літературно-науковий вістник, 1(1), с.103-113. [online] Доступно: 〈http: // chtyvo. org. ua / authors / Yovovych_Luka / Haiduky_obrazok_z_zhyttia_Chornohortsiv > [Дата звернення 19 вересня 2018]

Франко, І., 1977. Зібрання творів: У 50 m. T. 10. Із сербохорватської народної поезї̈. Київ: Наукова думка, с.86-108.

Франко, I., 1980. Зібрання творів: У 50 m. T. 26. Sagen und Märchen der Südslaven in ihrem Verhältnis zu den Sagen und Märchen der übrigen indogermanischen Völkergruppen, von Dr. Friedrich S. Krauss. I Band. Sagen und Märchen der Südslaven. Zum grossen Teil aus ungedruckten Quellen. Leipzig. Verlag von Wilhelm Friedrich, 1883. Київ: Наукова думка, с.285-288.

Франко, І., 1981а. Зібрання творів: У 50 m. Т. 31. Інтернаціоналізм і наиіоналізм у сучасних літературах. Київ: Наукова думка, с.33-44.

Франко, І., 1981b. Зібрання творів: У 50 т. Т. 32. Украӥнська література за 1898 р. Київ: Наукова думка, с.7-13.

Франко, I., 1986. Зібрання творів: У 50 m. Т 49. Лист до М. П. Драгоманова ([Відень], 13 червня 1893 р.). Київ: Наукова думка, с.406-407.

Франко, I., 2008а. Зібрання творів: У 50 m. Додаткові томи. Т. 51. 3 чорногорської літератури. Лука Йовович. Гайдуки. Образок з життя чорногориів. Київ: Наукова думка, с.803-812; Коментарі, с.947-948.

Франко, І., 2008b. Зібрання творів: У 50 m. Додаткові томи. Т. 52. Оригінальні та перекладні поетичні твори. Київ: Наукова думка, 1040 с.

Франко, І., 2008c. Зібрання творів: У 50 m. Додаткові томи. Т. 53. Фольклорний збірник Ф. Крауса. Київ: Наукова думка, с.427-429.

Хајдуковић, Л., 2006. Франков превод Лазаревићеве приповетке На бунару. В: Б., Косановић, уред. Иван Франко и срби: Зборник радова са међународног симпозијума одржаног у Новом Саду 25-27. Новембра 1996. Нови сад: Српскоукрајинско друштво; Архив Војводине, с.128-136.

Friedrich Salomon Krauss (1859-1938). [online] Available at: https://en.wikisource. org/wiki/Author:Friedrich_Salomon_Krauss [Accessed 1 september 2018]

Hajdarpasic, E., 2015. Whose Bosnia?: Nationalism and Political Imagination in the Balkans, 1840-1914. [online] Available at: <https://books.google.com.ua/books?isbn= 0801453712> [Accessed 19 september 2018]

Lekić, S., 2015. Luka Jovović - učitelj i književnik. Matica Crnogorska, s.349-362. [online] Available at: <http: // www. maticacrnogorska. Me / files / 64/ 15\%20savo\%20 lekic.pdf> [Accessed 14 May 2018]

Samardžija, M. i Selak, A., 2001. Leksikon hrvatskoga jezika i književnosti. Zagreb: Pergamena, 776p.

Sabljić, Ja., 2017. Pregled Crnogorske književnosti od 1852. do 1918. Milorada Nikčevića. Crnogorske filološke studije. Status i recepcija. Cetinje: FCJK, s.321-338. 


\section{References}

Franko, I., 1977. Collected Works: In 50 vols. Vol. 10. From Serbo-Croatian Folk Poetry. Kyiv, Naukova dumka, pp.86-108. (In Ukrainian)

Franko, I., 1980. Collected Works: In 50 vols. Vol. 26. Sagen und Märchen der Südslaven in ihrem Verhältnis zu den Sagen und Märchen der übrigen indogermanischen Völkergruppen, von Dr. Friedrich S. Krauss. I Band. Sagen und Märchen der Südslaven. Zum grossen Teil aus ungedruckten Quellen. Leipzig. Verlag von Wilhelm Friedrich, 1883. Kyiv: Naukova dumka, pp.285-288. (In Ukrainian)

Franko, I., 1981a. Collected Works: In 50 vols. Vol. 31. Internationalism and Nationalism in Modern Literatures. Kyiv: Naukova dumka, pp.33-44. (In Ukrainian)

Franko, I., 1981b. Collected Works: In 50 vols. Vol. 32. Ukrainian Literature for the Year 1898. Kyiv, Naukova dumka, pp.7-13. (In Ukrainian)

Franko, I., 1986. Collected Works: In 50 vols. Vol. 49. Letter to M. P. Drahomanov ([Vienna], 13 June 1893). Kyiv: Naukova dumka, pp.406-407. (In Ukrainian)

Franko, I., 2008a. Collected Works: In 50 vols. Additional Volumes. Vol. 51. From Montenegrin Literature. Luka Jovović. The Hajduks. A sketch from the life of Montenegrins. Kyiv: Naukova dumka, pp.803-812; 947. (In Ukrainian)

Franko, I., 2008b. Collected Works: In 50 vols. Additional Volumes. Vol. 52. From Serbian Folk Poetry. Kyiv: Naukova dumka, pp.727-728. (In Ukrainian)

Franko, I., 2008c. Collected Works: In 50 vols. Additional Volumes. Vol. 52. From Bosnian Herzegovinian Folk Poetry. Kyiv: Naukova dumka, pp.729-736. (In Ukrainian)

Friedrich Salomon Krauss (1859-1938). [online] Available at: https://en.wikisource.org /wiki/Author:Friedrich_Salomon_Krauss [Accessed 1 september 2018]

Hajdarpasic Edin, 2015. Whose Bosnia?: Nationalism and Political Imagination in the Balkans, 1840-1914. [online] Available at: <https://books.google.com.ua/books?isbn= 0801453712> [Accessed 19 september 2018]

Holberg, M., 1965. Franko's Translations from Serbian Prose. Slavonic Literary and Folklore Studies: Republican interdepartmental collection, 1, pp.160-172. Kyiv: Naukova Dumka. (In Ukrainian)

Holberg, M.Ya., 1990 [Discussion]. Ivan Franko and World Culture: Proceedings of the UNESCO International Symposium (Lviv, 11-15 September 1986). In 3 books, book 2. Kyiv: Naukova dumka, pp.298-300. (In Ukrainian)

Holberg, M. Ya., 2006. The Revealing of Ukrainian-Serbian Literary Relations: Results and Prospects. In: B.Kosanović, ed. Ivan Franko and the Serbs: Collected Papers from the International Symposium Held in Novi Sad, 25-27 Nov. 1996. Novi Sad: Serbian-Ukrainian Society: Vojvodine Archives, 2006, pp.164-165. (In Ukrainian)

Huts', M. V., 1966. South Slavonic Hajduk Epos and Serbo-Croatian Folk Lyrics in I. Ya. Franko's Translations. The Serbo-Croatian Folk Song in Ukraine. Kyiv: Naukova dumka. [online] Available at: rastko.rs〉 rastko-ukr/au/guc_pisnja_kn.html [Accessed 16 Feb. 2011] (In Ukrainian)

Jovović, L., 1898. Hayduky. Storiette of the Montenegrins' Life. Transl. from the Croat. by Iv[an] Franko. Literaturno-naukovyi vistnyk, 1(1), p.103-113. [online] Available at: <http: // chtyvo. org. ua / authors / Yovovych_Luka / Haiduky_obrazok_z_zhyttia_ Chornohortsiv> [Accessed 19 september 2018]. (In Ukrainian)

Khaiduković, L., 2006. Franko's translation of the short story by Lazarevic На бунару [By the Well]. In: B., Kosanović, ed. Ivan Franko and the Serbs: Collected Papers from the 
International Symposium Held in Novi Sad, 25-27 Nov. 1996. Novi Sad: Serbian-Ukrainian Society: Vojvodine Archives, 2006. (In Serbian)

Samardžija, M. and Selak, A., 2001. Lexicon of Croatian language and literature. Zagreb: Pergamena, 776 p. (In Croatian)

Lekić, S., 2015. Luka Jovović - učitelj i književnik [Luka Jovović - Teacher and Writer]. Matica Crnogorska, s.349-362. [online] Available at: <http: // www. maticacrnogorska. Me / files / 64/ 15\%20savo\%20lekic.pdf> [Accessed 14 May 2018] (In Croatian)

Sabljić, J., 2017. Pregled Crnogorske književnosti od 1852. do 1918. Milorada Nikčevića. Crnogorske filološke studije. Status i recepcija. Cetinje: FCJK, 2017. s.321-338. (In Montenegrin)

\title{
БОСНІЙСЬКО-ГЕРЦЕГОВИНСЬКА ТА ЧОРНОГОРСЬКА ЛІТЕРАТУРА У КОЛІ ТВОРЧИХ ЗАЦІКАВЛЕНЬ ІВАНА ФРАНКА
}

\author{
Іван ТЕПЛИЙ \\ Львівський національний університет імені Івана Франка \\ вул. Університетська, 1, Львів, 79000 \\ Кафедра іноземних мов для гуманітарних факультетів \\ e-mail:i_teplyy@yahoo.co.uk
}

Постановка проблеми: Творчий перекладацький доробок I. Франка у розглядуваній царині кількісно не такий уже й великий, але він дає змогу проілюструвати низку наукових положень, має значний евристичний потенціал, велику теоретичну цінність, що вже дало підставу низці дослідників зробити важливі теоретичні висновки.

Мета: У розвідці розглянуто переклади, образні аналогії, інші форми реалізації іншомовного дискурсу, над якими активно працював I. Франко. Значну увагу приділено чорногорцю Луці Йововичу, першопублікацію якого - образок "Гайдуки" (Журнал "Луча") - I. Франко переклав і доповнив літературознавчою довідкою про автора.

Результати дослідження: У відомій статті “Інтернаціоналізм і націоналізм у сучасних літературах” I. Франко, зокрема й на прикладі Луки Йововича, обгрунтував ідею близькості національної за формою творчості письменників різних народів до загальнолюдських почувань, а саме: такі митці будуть одночасно зрозумілі і цікаві не тільки своїм землякам, а й цілому цивілізованому світу, бо всі знайдуть у їхніх творах, попри незвичайність та національну неповторність їх форми, ті самі почуття, сумніви, страждання, симпатії й антипатії, які становлять суть освіченої людини свого часу.

Важливе місце у дослідженнях I. Франка посідають питання інтертекстуальності, а також міжслов'янських літературно-наукових зв' язків.

Суттєво різняться творчі стилі І. Франка як перекладача-поета і перекладачапрозаїка. На матеріалі сербської літератури між ними, як видається, існує антиномія (вельми вдалі переклади поетичних творів та не завжди такі переклади прози), однак у перекладах з інших літератур, про які тут йдеться, такого контрасту не спостерігається. 3 огляду на це, наступним кроком, тобто дослідженням на зазначену проблематику, міг би, цілком ймовірно, стати аналіз Франкового перекладу “Гайдуків" та першотвору Луки Йововича.

Ключові слова: дискурс, переклад, література, образок, зміст, форма, національний, загальнолюдський. 